\title{
Visitation capacity study of the ecological trail of an Atlantic Forest fragment
}

The study of the visitation capacity or load capacity aims to evaluate the intensity of the public use in areas of visitation. In order to determine the carrying capacity of the Interpretive Trail of Marist Social Center of Dourados (MSC), a research was carried out to analyze, identify and record information about the trail. The method was adapted and based on three types of capacity - physical, real and effective, considering the Correction Factors associated to the physical aspects, interference in fauna and flora, equipment and infrastructure, management and flow of visitation. Thus, it was established that the reservation trail of the Marist Social Center of Dourados, with a length of 450 meters, has a capacity of 40 visitors per day, with 30 minutes being established for each group during the track circuit. However, in order to reduce impacts during the trail, a management plan should be established to minimize the impacts of visitation.

Keywords: Load capacity; Forest reserve; Conservation of protected natural areas.

\section{Estudo da capacidade de visitação de uma trilha ecológica em um fragmento de Mata Atlântica}

O estudo da capacidade de visitação ou capacidade de carga visa avaliar a intensidade do uso público em áreas de visitação. Para determinar a capacidade de carga da Trilha Interpretativa do Centro Social Marista de Dourados (CSM) realizou-se uma pesquisa com objetivo de analisar, identificar e registrar informações sobre a trilha. O método foi adaptado e baseado em três tipos de capacidade - física, real e efetiva, considerando os Fatores de Correção associados aos aspectos físicos, de interferência na fauna e flora, equipamentos e infraestrutura, gerenciais e fluxo de visitação. Assim, foi estabelecido que a trilha da reserva do Centro Social Marista (CSM) com comprimento de 450 metros comporta uma capacidade de 40 visitantes por dia, sendo estabelecido 30 minutos para cada grupo durante 0 circuito da trilha. No entanto, ainda a fim de reduzir os impactos durante a trilha deve-se estabelecer um plano de manejo para minimizar os impactos da visitação.

Palavras-chave: Capacidade de carga; Reserva florestal; Conservação de áreas naturais protegidas.

Topic: Planejamento, Gestão e Políticas Públicas Ambientais

Reviewed anonymously in the process of blind peer.

Emerson Machado de Carvalho (iD

Universidade Federal do Sul da Bahia, Brasil

http://lattes.cnpq.br/7341724276580365

http://orcid.org/0000-0002-4865-6784

carvalho.em@gmail.com

Ana Paula Lemke (iD

Universidade Estadual de Mato Grosso do Sul, Brasil

http://lattes.cnpq.br/2531796565066894

http://orcid.org/0000-0003-2396-6126

anapaulalemke@yahoo.com.br

Rosilda Mara Mussury (iD

Universidade Federal da Grande Dourados, Brasil

http://lattes.cnpq.br/8308188020990220

http://orcid.org/0000-0002-8961-9146

mussuryufgd@gmail.com
Received: 19/03/2020

Approved: 22/04/2020
André Luis Corrêa

Universidade Estadual de Santa Cruz, Brasil

http://lattes.cnpq.br/1817853337685773

http://orcid.org/0000-0002-7303-221X

alcorrea@uesc.br

Fernanda Jordão Guimarães (iD)

Universidade Estadual de Santa Cruz, Brasil

http://lattes.cnpq.br/517085265752185

http://orcid.org/0000-0002-2331-5801

fjguimaraes@uesc.br
Referencing this:

CARVALHO, E. M.; LEMKE, A. P.; MUSSURY, R. M.; CORRÊA, A. L.; GUIMARÃES, F. J.. Visitation capacity study of the ecological trail of an Atlantic Forest fragment. Revista Ibero Americana de Ciências Ambientais, v.11, n.3, p.402-410, 2020. DOI: http://doi.org/10.6008/CBPC2179-6858.2020.003.0031

DOI: 10.6008/CBPC2179-6858.2020.003.0031 


\section{INTRODUCTION}

Trails and paths are probably the most widespread travel routes in the world (LECHNER, 2006). It has been related to human being since his first discoveries and certainly still provokes this sense of exploration, pioneering activities, and interpretation of the world around him. And this is one of the main functions in planning interpretive trails in natural landscapes.

The interpretative trail can be understood as one of the environmental education methodology that help to promote people perception, so that they can arouse interest in preserving a space to which they have access and contact with species (AMARAL et al., 2007). Environmental education through interpretative trail is, however, method for bringing people closer to the natural environment, combining curiosity, imagination, knowledge and reflection about the human-nature relationship (VASCONCELOS, 1998).

If well planned, the interpretive trail can attract a large number of nature admirers, especially those from urban backgrounds, who seek proximity and experience with little transformed environments, for leisure, hiking, visitation, environmental studies or simply for contemplation. There is a growing recognition that local population involvement is the main element in management and conservation strategies (AMARAL et al., 2007; LECHNER, 2006).

In terms of Landscape Ecology, the trail is structurally a corridor defined by clearing the vegetation to establish the trampling zone (useful area actually used by the user in its displacement) and the marginal management area, where the vegetation is kept under control to prevent it from closing. This set composes what is called the "corridor" of the trail (MELLO et al., 2012). Walking on trails is an ancient skill of the human being, motivated mainly by the need for commuting. However, in recent years, the walk has incorporated a new meaning. From a simple means of displacement, they became a new means of contact and integration with nature (ANDRADE, 2003).

The desire for contact and observation of preserved nature turn the trails in built paths with the aim of bringing the visitor closer to the natural environment and acting as a space for interaction and familiarity with the environment (KROEFF et al., 2011). However, these built paths can present different formats, extensions, degrees of difficulty, meanings that, in certain way, will imply different objectives.

For Andrade et al. (2008), the trails can also be classified according to function, form and degree of difficulty. In order to bring the visitor closer to nature, the short-distance trails have a recreational and educational character with programming developed for the interpretation of the natural environment. However, the long-distance ones have recreational character as crossing trips. As for the degree of difficulty, the classification is quite subjective, as it varies from person to person, depending basically on the physical condition and weight of any luggage (backpack) carried. They can be classified according to the guiding criteria as easy, medium, hard and very difficult. They may also indicate physical dependence on visitors as easy, or as demanding, tiring and strenuous fitness. They may involve the level of difficulty, such as simple, uphill and downhill routes, requiring hands to use on dangerous or height-exposed stretches, very exposed and dangerous stretches where the use of ropes is indispensable (MENESES, 1998). 
Regarding the layout of the trail in space, the circular shape may offer the possibility of returning to the beginning without repeating the route or crossing with other visitors. The track in shape of eight is very efficient in limited areas, thus increasing the possibility of using the space. The linear track is the simplest and most common shape and its goal is to reach some point of interest. In the shortcut trail, the beginning and end are in different locations. The ideal type of trail for each location will depend on a number of factors such as geomorphology, available resources, size of the area, audience involved, degree of difficulty, among others.

However, whatever the trail classification is, it is important to keep in mind that there are many details to consider for the efficient planning and management of natural environment. In the generic context it is noteworthy that the trails provide access to attractions and also the most remote areas (SOUZA, 2014; PFEIFER et al., 2017), which without proper planning and management can bring more negative impacts than positive to the environment. So, it needs an efficient tool that assesses the environmental impact taking into account the visitation capacity of the site. Visitation capacity, also called as load capacity, in tourist resorts, was primarily used by biology and livestock. The first referred to the number of animals that could be kept in a given habitat without the occurrence of biological and ecological impacts. The second aimed to establish the number of animals that could use a pasture area without causing irreversible damage to the environment (TAKAHASHI, 2004).

We understand as visitation or load capacity of a tourist resort is the maximum number of visitors (per day/month/year) that an area can support before changes in the physical and social environment occur (OLIVEIRA, 2003). Measurement of visitation capacity may vary greatly in the literature. Cifuentes (1992) proposes a calculation based on the maximum number of visits a protected area can receive during a day, taking into account the physical, biological and management conditions that appear at the time of the study.

Among the variables involved in the study of visitation capacity, the following determinations are of paramount importance: (1) physical load capacity (PLC), which defines the maximum limit of visits that can be allowed in one place at a given time; (2) Real load capacity (RLC), which is the maximum visit limit determined from the PLC of a location, after applying the correction factors defined as a function of the particular characteristics of the study area; (3) effective load capacity (ELC), which is the maximum number of visits that can be allowed, given the ability to handle and order them (GALVÃO-BUENO et al., 2004). However, the procedures for determining it vary from place to place, as there can be no fixed qualitative and quantitative values, as seasonal conditions, cultural values, tourists, the region infrastructure, environmental uses and dynamism vary (FENNELL, 2002).

In Brazil most of the trails originated from open paths in the middle of the forest, popularly called "picada" (shortcut opened using a cutting instrument). These paths were built without any planning and, in the vast majority of cases, maintenance is inadequate or even nonexistent, which endangers, in addition to ecosystem stability, the safety of visitors (TAKAHASHI, 1998). Thus, the aim of the present study was to define the visitation capacity of an interpretive trail in a small forest fragment located in the Marist Social Center of Dourados (Dourados/MS). 


\section{MATERIALS AND METHODS}

\section{Area Characterization}

The study area is located within the Marist Social Center (MSC) in the urban perimeter of Dourados $\left(22^{\circ} 13^{\prime} 57.83^{\prime \prime S}, 54^{\circ} 46^{\prime} 8.04^{\prime \prime} 0\right)$, in the southern region of Mato Grosso do Sul State, which has on its property a natural forest of approximately 1.2 hectares, which shelters a small population of capuchin monkeys (Figure 1).

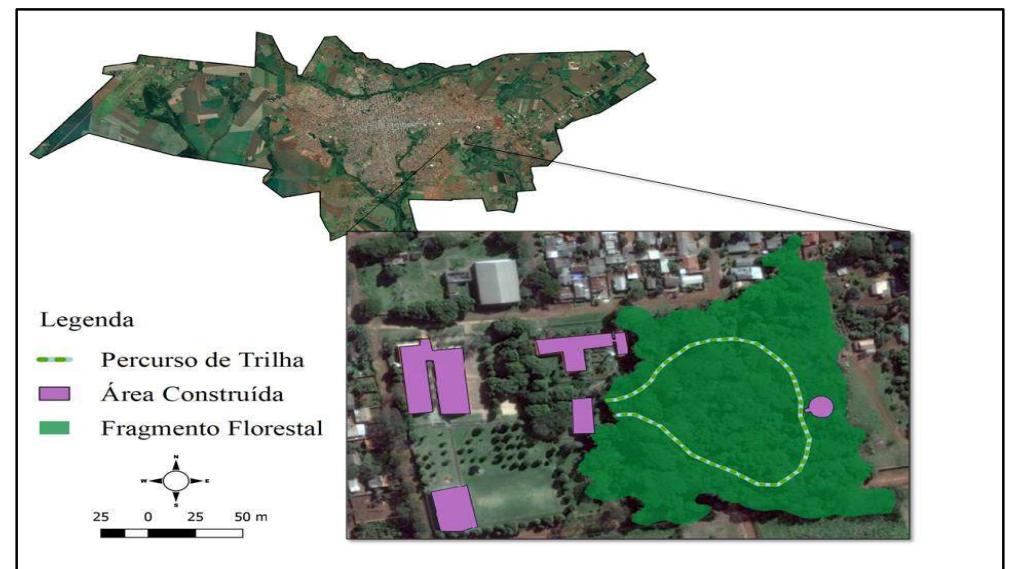

Figure 1: Location of the interpretive trail in the forest fragment located at the Marist Social Center of Dourados (Dourados/MS).

The predominant vegetation in the study area is submontane semi-deciduous seasonal forest with the soil of the Oxisol. The ecological concept of this type of vegetation is conditioned by the dual climatic seasonality: a tropical one, with intense summer rains followed by severe droughts; and another subtropical, without dry period, but with physiological drought caused by intense winter cold, with average temperatures below $15^{\circ} \mathrm{C}$ (BOSA et al., 2011). The study was conducted through a field survey, from October to November 2015, during the daytime. Data were collected throughout the trail and during visitation times.

\section{Visitation capacity}

The visitation capacity calculation, according to the method proposed by Cifuentes (1992), is used to establish the maximum limit of visitors on a trail during a day. According to the author there are three levels of load capacity: Physical Load Capacity (PLC), Real Load Capacity (RLC) and Effective Load Capacity (ELC).

Physical Load Capacity - PLC: is the maximum limit of visitors that can occupy a defined space in a given time; while the Real Load Capacity - RLC: is identified after the PLC value correction on correction factors obtained when considering environmental, physical, ecological and management variations; and the Effective or Permitted Load Capacity - ELC: is the maximum limit of permissible visits according to the CM Management Capacity of the area. The relationship among them is established such that the Physical Load Capacity is always greater than or equal to the Real Load Capacity, which in turn will always be greater than or equal to the effective load capacity.

\section{$P L C \geq R L C \geq E L C$}

PLC lists the following visit factors: travel time; trail length and space requirement per visitor. The 
relationship between these factors is represented by the equation:

$$
\mathrm{PLC}=\mathrm{T} \cdot \mathrm{A} \cdot \mathrm{Hv} / \mathrm{Tv}
$$

Where:

$\mathrm{T}=$ available track surface in linear meters

$A=$ Area used by each person

$\mathrm{Tv}=$ Time required for each visit

$\mathrm{Vh}=$ Visiting hours

Real Load Capacity (RLC) will be estimated by multiplying each of the correction factors calculated by the value obtained for Physical Load Capacity (PLC). For the calculation of the Real Load Capacity (RLC) the following Correction Factors (CF) were applied:

$$
\begin{gathered}
x 1(C F \times 1) ; x 2(C F \times 2) \text { and } x n(C F x n) . \\
\text { RLC }=\text { PLC } x \sum \text { CF }
\end{gathered}
$$

Correction factors were determined from a list of indicators that act directly on the trail, and those chosen for CF determination were those that were classified as high. The evaluation was made through grades: 1 (one) represents an undesirable condition; 2 (two) represents a regular condition and 3 (three) represents a desirable condition. It was considered as critical point the parameters that represented an undesirable condition. Table 1 shows the correction factors as well as their relevance/magnitude that were

\begin{tabular}{|c|c|c|c|c|}
\hline \multirow{3}{*}{$\mathbf{N}$} & \multirow{3}{*}{ Indicators } & \multicolumn{3}{|c|}{ Parameters } \\
\hline & & High & Moderate & Little \\
\hline & & 1 & 2 & 3 \\
\hline 1 & Risk of falling trunk and trees & & $\mathrm{x}$ & \\
\hline 2 & Risk of falling into holes & & & $\mathrm{X}$ \\
\hline 3 & Risk of accidents with social insects & & $\mathrm{x}$ & \\
\hline 4 & Wild animal accident risk & & & $\mathrm{X}$ \\
\hline 5 & Risk of accidents with special needs visitors & & $\mathrm{x}$ & \\
\hline 6 & Risk of accidents with urticaria plants & & & $\mathrm{X}$ \\
\hline 7 & Soil compaction & & $\mathrm{X}$ & \\
\hline 8 & Soil exposure & & $\mathrm{X}$ & \\
\hline 9 & External noise interference & $\mathrm{X}$ & & \\
\hline 10 & Loss of soil vegetation cover & & $\mathrm{x}$ & \\
\hline 11 & Modification of fauna behavior & & $\mathrm{x}$ & \\
\hline 12 & Soil sealing & & & $\mathrm{X}$ \\
\hline 13 & Erosive process & & & $\mathrm{X}$ \\
\hline 14 & Occurrence of invasive plants & $\mathrm{X}$ & & \\
\hline 15 & Lack of waste disposal bins & $\mathrm{x}$ & & \\
\hline 16 & Lack of biodiversity surveys and surveys & & $\mathrm{X}$ & \\
\hline 17 & Lack of preventive measures against accidents & $\mathrm{X}$ & & \\
\hline 18 & Lack of track cleaning and maintenance & & $\mathrm{X}$ & \\
\hline 19 & Lack of trail boundary & & & $\mathrm{X}$ \\
\hline 20 & Track width in relation to forest size & & $\mathrm{X}$ & \\
\hline 21 & Erosion containment drains are missing & $\mathrm{X}$ & & \\
\hline 22 & Lack of drains to minimize flood points & $\mathrm{x}$ & & \\
\hline 23 & Lack of adequately trained and skilled staff & & $\mathrm{X}$ & \\
\hline 24 & Presence of solid waste within the reserve & & $\mathrm{X}$ & \\
\hline 25 & Flooding points during the rain & & $\mathrm{X}$ & \\
\hline 26 & Border effects & $\mathrm{x}$ & & \\
\hline 27 & No damping zone & $\mathrm{x}$ & & \\
\hline 28 & Noise interference by visitors themselves & $x$ & & \\
\hline 29 & Occurrence of Exposed Roots & & & $\mathrm{X}$ \\
\hline
\end{tabular}
identified as high relevance or magnitude.

Table 1: Correction factors identified and assigned score indicated by $X$. 
Correction Factors were calculated from the following general formula:

$$
\mathrm{CFn}=1-\frac{\mathrm{LMn}}{\mathrm{TMn}}
$$

Where:

$\mathrm{CF}=$ Correction Factor $\mathrm{n}(\mathrm{x} 1, \mathrm{x} 2, \mathrm{xn})$;

$\mathrm{LMn}=$ Limiting Magnitude $\mathrm{n}$;

$\mathrm{TMn}=$ Total Magnitude $\mathrm{n}$.

Effective Load Capacity (ELC) represents the number of visits allowed on a trail or tourist site. It is obtained by multiplying the value obtained in the calculation of Real Load Capacity (RLC) by the percentage established for handling capacity. This study considers the value of 0.75 or $75 \%$ of the optimal value for management capacity, and according to Cifuentes (1992) this value is considered satisfactory for management capacity.

$$
E L C=R L C \times 0,75
$$

\section{RESULTS AND DISCUSSION}

The studied trail can be classified as a 'shortcut trail', i.e. the beginning and end are in different locations. Given that its length is less than $500 \mathrm{~m}$, it is a short trail, defined as mild difficulty that requires little effort in walking, and can be used by visitors who do not practice physical activities and without experience in hiking. To calculate the physical capacity, the parameters were identified as presented in Table 2.

Table 2: Parameters assigned to survey Physical Load Capacity.

\begin{tabular}{|l|l|}
\hline Parameters & Value \\
\hline $\mathrm{T}=$ Track Surface & 450 meters \\
\hline $\mathrm{A}=$ Area used by each person & 1 meter \\
\hline $\mathrm{T}=$ Time required for each visit & 30 minutes \\
\hline $\mathrm{Vh}=$ Visiting hours & 4 hours \\
\hline
\end{tabular}

The calculation was established according to the following equation:

$$
\text { PLC }=450 * 1 * \frac{4}{0,5}=3.600
$$

To adjust the PLC is necessary to calculate the correction factor, as established in Table 1. From this it was calculated the correction factors for the most relevant indicators, shown in Table 3.

Table 3: Track-relevant correction factors

\begin{tabular}{|l|l|c|}
\hline CF- Correction Factor & Relevance or Magnitude & Result \\
\hline $\begin{array}{l}\text { CF9 - External noise } \\
\text { interference }\end{array}$ & Average value established by field observation & CF(external r) $=0.7$ \\
\hline $\begin{array}{l}\text { CF28 - Internal noise } \\
\text { interference }\end{array}$ & $\begin{array}{l}\text { The higher the number of visitors on the trail (average value } \\
\text { established by field observation) }\end{array}$ & CF(internal r) $=0.7$ \\
\hline $\begin{array}{l}\text { CF14 - Occurrence of } \\
\text { invasive plants }\end{array}$ & $\begin{array}{l}\text { Presence of invasive plants in the trail (average value established } \\
\text { by field observation) }\end{array}$ & $\mathrm{CF}($ plants) $=0,7$ \\
\hline $\begin{array}{l}\text { CF15 - Dumpsters along the } \\
\text { trail }\end{array}$ & Number of dumpsters along the trail & $\begin{array}{c}\mathrm{CF}(\text { dumpsters })=1-\frac{1}{4}= \\
0.75\end{array}$ \\
\hline $\begin{array}{l}\text { CF17 - Accidents along the } \\
\text { trail }\end{array}$ & Possibility of incidents & $\mathrm{CF}$ (accidents) $=0.25$ \\
\hline
\end{tabular}




\begin{tabular}{|l|l|c|}
\hline CF21 - Erosion control & Presence of areas susceptible to erosion in 200m of trail & CF(erosion) $=1-\frac{200}{450}=0.55$ \\
\hline CF22 - Flood Area Control & Presence of areas susceptible to flooding in $100 \mathrm{~m}$ of trail & $\mathrm{CF}(\mathrm{flooding})=1-\frac{100}{450}$ \\
\hline CF26- Border effect & Average value established by field observation & 0.978 \\
\hline CF27- buffer zone & Average value established by field observation & 0.6 \\
\hline$\sum \mathrm{CF}=0.01452$ & 0.7 \\
\hline
\end{tabular}

For RLC we have:

$$
\mathrm{RLC}=\mathrm{PCL} X \sum \mathrm{CF}=3600 * 0.01452=52.31 \text { people }
$$

For the effective load capacity (ELC), it is considered as CCM at 0.75 , then:

$$
\begin{gathered}
\mathrm{ELC}=\mathrm{RLC} \times 0.75=52.31 * 0.75 \\
\mathrm{ELC}=40 \text { people }
\end{gathered}
$$

Determining the Effective Load Capacity (ELC) value allows us to establish the maximum number of visitors per day the trail can receive, while respecting the carrying capacity of the environment. Thus, the management plan of the interpretative trail in question must take into account the maximum limit of 40 people/day of visitation. Given that the trail is only 450 meters long in an area of 1.2 hectares, it is recommended that each trail be made with up to 10 people per guide.

In addition to the ability to visit each day, it is important to consider the maximum number of people per route to maintain the quality and interpretive and informative objectives of the trail. For this, it was observed during the visits that more than 10 people the information passed by the guide did not reach the last visitors, dispersing the group and causing parallel conversations. Even if a school class exceeds this number limit, they can be divided into teams of 10 people, with entry intervals every 30 minutes or until the guide returns.

Different values of Effective Load Capacity can be found in the literature. The results found by Seabra (2005) and Cifuentes (1999), for example, are distinct from each other and with the value calculated in this paper. This is due to the intrinsic characteristics of each of the evaluated trails. The Cifuentes' methodology (1992; 1999) makes it easier to control visitation, since the calculations determine the maximum number of people who can visit the site and from this one can establish control, management and mitigation measures of impacts on the environment.

It is foreseen in the Project of the interpretative track of Marist Social Center (MSC) of Dourados that the hours of attendance should be contemplated at most 04 (four) times a week, being 03 (three) days of attendance for the educative community, and on Sundays directed to the community in general. It was determined by the management of MSC of Dourados that at the first moment can only offer a maximum of 4 hours of operation, given the lack of employees for the activities related to the trail visitation.

The carrying capacity defined for a given area is relative and to some extent subjective and should consider a certain flexibility in its adoption. The figures given by the studies may change slightly according to the environmental situation. This is because their values depend on variable factors and conditioning factors and need to be continually reevaluated. Therefore, monitoring of the evaluated areas based on the indicators 
presented is essential to support management decisions. Therefore, the practice of environmental education within the trail is relevant in order to guide the behavior of visitors along the route, which will also benefit the compilation of data for studies of tourist load capacity.

\section{CONCLUSIONS}

The adopted method was adequate to identify and raise the main indicators for determining the tourist load capacity. Such definitions will allow administrators to optimize the use of resources, prioritizing monitoring those that best reflect the conditions of the area. This method was oriented to respect the local particularities, their knowledge and practices, as well as to promote the active participation of those involved in the Project of the interpretative trail of Marist Social Center (MSC) of Dourados for the adaptations of the study.

In short, it was established that the MSC reserve trail is short-lived, low-difficulty and easy to guide, with a capacity of 40 visitors per day and 30 minutes for each group along the way. However, a management plan should be established to minimize the impacts of visitation. This plan should contain the actions of cleaning, control of erosion and flooding processes, monitoring of flora and fauna, control of invasive plants and other measures.

\section{REFERENCES}

AMARAL, A. G.; MUNHOZ, C. B. R.. Planejamento do traçado de uma trilha interpretativa através da caracterização da flora do Parque Ecológico e de Uso Múltiplo Águas Claras, DF. Revista Brasileira de Biociências, Porto Alegre, v.5, n.1, p.639-641, 2007.

ANDRADE, W. J.. Implantação e manejo de trilhas. In: Manual de Ecoturismo de Base Comunitária: ferramentas para um planejamento responsável. Brasília: WWF Brasil, 2003.

ANDRADE, W. J.; ROCHA, R. F.. Manejo de trilhas: um manual para gestores. Instituto Floresta Série Registros, São Paulo, n.35, p.1-74, 2008.

BOSA, C. R.; ADERLAN, J.. Abordagem histórica de uma mata destinada a conservação ambiental no município de Dourados/MS. Monografias ambientais, Santa Maria, v.2, n.2, p.228-240, 2011.

CIFUENTES, M. A.. Determinación de capacidad de carga turística en áreas protegidas. CATIE, 1992.

CIFUENTES, M. A.. Capacidad de carga turística de las áreas de uso público del monumento nacional guayabo, costa Rica. Turrrialba: CATIE, 1999.

FENNELL, D. A.. Ecoturismo: uma introdução. São Paulo: Contexto, 2002.

GALVÃO-BUENO, M. S.; LOPES, T. A. P.; OBST, R. A.. Determinação da capacidade de carga turística da trilha da cachoeira do núcleo engordador, parque estadual da Cantareira (SP), para subsidiar o controle do impacto decorrente da visitação pública. FAENAC de Turismo, São Caetano do Sul, v.54, n.1, p.33-1, 2004.

KROEFF, L. L.; VERDUM, R.. Identificação de Áreas potenciais ao mapeamento de trilhas ecoturísticas na propriedade do Ecoparque, em Canelas/RS. Revista brasileira de Geomorfologia, Brasília, v.12, n.3, p.31-136, 2011.

LECHNER, L.. Planejamento, implantação e manejo de trilhas em unidades de conservação. Curitiba: Fundação $O$ Boticário de Proteção à Natureza, 2006.

MENEZES, P. C.. Novas Trilhas do Rio. Rio de Janeiro: Sextante, 1998.

MELLO, F. A. P.; COSTA, N. M. C.. Reflexões sobre as relações entre trilhas e a biodiversidade em áreas protegidas brasileiras. In: CONGRESO DE PLANIFICACIÓN Y MANEJO SE SENDEROS DEL MERCOSUR. Anais. Piriápolis, 2012.

OLIVEIRA, P. Q.. Capacidade de carga nas cidades históricas. Campinas: Papirus, 2003.

PFEIFER, F. J.; QUADROS, A. S.; SIQUEIRA, A. B.; NEIS, F. A.; KONFLANZ, T. L.. A trilha sensitiva como prática de educação ambiental para alunos de uma escola de ensino fundamental de Palmeira das Missões/RS. Revista Eletrônica do Mestrado em Educação Ambiental, p.67-84, 2017. DOI: https://doi.org/10.14295/remea.v0i0.5062

SEABRA, L. S.. Monitoramento participativo do turismo desejável: Contribuição aos estudos de capacidade de suporte turístico. 2005. 
SOUZA, M. C. C.. Educação ambiental e as trilhas: contexto para a sensibilização ambiental. Revista Brasileira de

Educação Ambiental, São Paulo, v.9, n.2, p.239-253, 2014.

TAKAHASHI, L. Y.. Uso Público em Unidades de

Conservação. Curitiba: Fundação O Boticário de Proteção à Natureza, 2004.
VASCONCELOS, J.. Avaliação da visitação pública e da eficiência de diferentes tipos de trilhas interpretativas no Parque Estadual Pico do Marumbi e Reserva Natural Salto Morato/PR. Tese (Doutor em Ciências Agrárias) Universidade Federal do Paraná, Curitiba, 1998.

A CBPC - Companhia Brasileira de Produção Científica (CNPJ: 11.221.422/0001-03) detém os direitos materiais desta publicação. Os direitos referem-se à publicação do trabalho em qualquer parte do mundo, incluindo os direitos às renovações, expansões e disseminações da contribuição, bem como outros direitos subsidiários. Todos os trabalhos publicados eletronicamente poderão posteriormente ser publicados em coletâneas impressas sob coordenação da Sustenere Publishing, da Companhia Brasileira de Produção Científica e seus parceiros autorizados. Os (as) autores (as) preservam os direitos autorais, mas não têm permissão para a publicação da contribuição em outro meio, impresso ou digital, em português ou em tradução. 